\title{
PEDRO PAULO A. FUNARI AND AMPHOROLOGY
}

\author{
Haiganuch Sarian ${ }^{1}$
}

When Pedro Paulo Funari asked me to supervise his researches, while he was aiming at an MSc program, his ideas about the theme to be addressed were already well-defined. More than this, at a very young age, he already had good knowledge of the bibliography aboutthis theme, namely the universe of Roman amphorae and their economic implications.

During the time of our supervisor-student relation - which became a source of immense contentment for me, as a result of his great commitment -, the initial elements of a Dressel 20 category of amphorae began to ripen as he progressed. These amphorae date to the 1 st_-3rd centuries AD, particularly ca. $194 \mathrm{AD}$, and they are named after German archeologist and epigraphist Heinrich Dressel (1845-1920), who developed a typology for amphorae. The Dressel 20 amphorae were originally from Baetica, a province of Roman Hispania.

Thus, between 1982 and 1985, as a holder of CNPq and FAPESP scholarships, Pedro Paulo Funari carried out his MSc researches and presented a dissertation with the title "The morphological transformations of Baetican Dressel 20 oil amphorae" ["As transformações morfológicas das ânforas oleárias béticas do tipo Dressel 20"] at the Department of Anthropology at FFLCH-USP.

His reflections on this theme led him to publish a study that defined the status of the researches on amphorae:

- A Anforologia: uma nova disciplina arqueológica ["Amphorology: a new archaeological discipline", in Portuguese]. Revista de História, São Paulo: FFLCH-USP, v. 118, 1985, p. 161-170.

As a good ceramologist, Funari was also concerned with finding the original classification of Roman vases in Latin vocabulary. Thus, he published the following two articles:

\footnotetext{
1 Senior Full Professor, University of São Paulo, São Paulo, Brazil. E-mail: haigasarian@gmail.com
} 
- Em torno da ânfora. A terminologia latina dos vasos recipientes. ["Around theamphora: The Latin terminology of storage vessels", in Portuguese] In: PINTO, N. F.; BRANDÃO, J. L. (Orgs.). Cultura Clássica em Debate. Anais do I Congresso Nacional de Estudos Clássicos. Belo Horizonte: UFMG/CNPq/SBEC, 1987, p. 51-60. This study was also published in Italian:

- Considerazioni sull'anfora e la terminologia latina dei vasi recipienti. ["Considerationson amphorae and the Latin terminology of storage vessels", in Italian] Limes. Santiago do Chile: Universidad Metropolitana de Ciencias de la Educación: Centro de Estudios Clásicos, v. 12, 2000, p. 106-115.

From 1986 to 1990, Funari dedicated himself to the researches of his PhD thesis, as holder of a CAPES scholarship. He brilliantly presented his study "Baetican oil consumption standards in Roman Britain" ["Padrões de consumo do azeite bético na Bretanha Romana"] at the Department of Anthropology at FFLCH-USP. At that point, his concerns with the contents of amphorae and with economic life started to emerge in addition to his typological studies.

The following references are some significant articles based on the experience and reflections of Prof. Funari from his MSc and $\mathrm{PhD}$ trajectories:

- Estudo tipológico das ânforas oleárias béticas (Dressel 20) de ca. 149 d.C. ["A typological study of Baetican (Dressel 20) oil amphorae from ca. 149 AD", in Portuguese]. Dédalo. São Paulo: MAE-USP, v. 25, 1987, p. 209-233 (part of Prof. Funari's MSc research).

- A produção e o consumo de vinho na Antiguidade Clássica. Um balanço dos estudos anfóricos recentes ["Wine production and consumption in Classical Antiquity. A review of recent studies on amphorae", in Portuguese]. Revista da Sociedade Brasileira de Pesquisa Histórica. Curitiba: SBPH, v. 7, 1992, p. 77-78.

- Baetica and the Dressel 20 production. An outline of the province's history. Dialogue d'Histoire Ancienne. Besançon: Institut des Sciences et Techniques de l'Antiquité, Université de Franche-Comté, v. 20, n. 1, 1994, p. 87-105.

- Les amphores du Sado, Portugal. Prospection des fours et analyse du matériel ["The Sado amphoraein Portugal. A prospection of their ovens and analysis of materials", in French]. American Journal of Archaeology. Boston: Archaeological Institute of America, v. 102, n. 2, 1998, p. 452-453. 
With his keen erudition and scientific maturity, Prof. Funari presented his Free Professorship thesis in 1995 at the University of Campinas (UNICAMP) with the title "The Dressel 20 inscriptions from Britain and the consumption of Spanish oil, with a Catalogue of seals" ["As inscrições Dressel 20 provenientes da Bretanha e o consumo do azeite espanhol, com um Catálogo de selos"], in 2 volumes.

Before his Free Professorship thesis and soon after its presentation, Prof. Funari became a specialist in Latin epigraphy, particularly in amphoric epigraphy. Since then, his numerous contributions to this area have included the following highlights:

- Uma inscrição bética inédita dos anos 90 d.C.: observações preliminares ["Preliminary notes on a new Baetican inscription from the decade of $90 \mathrm{AD}$ ", in Portuguese]. Revista do Departamento de História. Belo Horizonte: Universidade de Minas Gerais, NESP 7, 1988, p. 90-101.

- Dressel 20 amphora inscriptions found at Vindolanda: the Reading of the unpublished evidence. In: MASFIELD, V.A.; DOBSON, M.J. (Eds.). Roman frontier studies 1989. Exeter: University of Exeter Press, 1991, p. 65-72.

- As inscrições béticas inéditas provenientes de Vindolanda ["The new Baetican inscriptions from Vindolanda", in Portuguese]. Classica: Revista Brasileira de Estudos Clássicos. São Paulo: Sociedade Brasileira de Estudos Clássicos, v. 5, n. 1, 1993, p. 157-166.

- Some amphora inscriptions from Britain: amphora evidences. Revista do Museu de Arqueologia e Etnologia. São Paulo: MAE-USP, v. 3, 1993, p. 121135.

- Avanços recentes no estudo da Epigrafia Latina das ânforas oleárias béticas ["Recent strides in the study of Latin epigraphy based on Baetican oil amphorae", in Portuguese]. Boletim do CPA. Campinas: UNICAMP/IFCH, v. 7, 1995, p. 363-368.

Even though some articles written by Prof. Funari's did reach beyond the Brazilian frontiers, it was doubtlessly the publication of his Free Professorship thesisby a prestigious collection in the United Kingdom that deserves our best compliments:

- Dressel 20 inscriptions from Britain and the consumption of Spanish olive oil. Oxford: Tempus Reparatum - BAR 250, 1996, 137 p., maps, illustrations (Figure 1). 


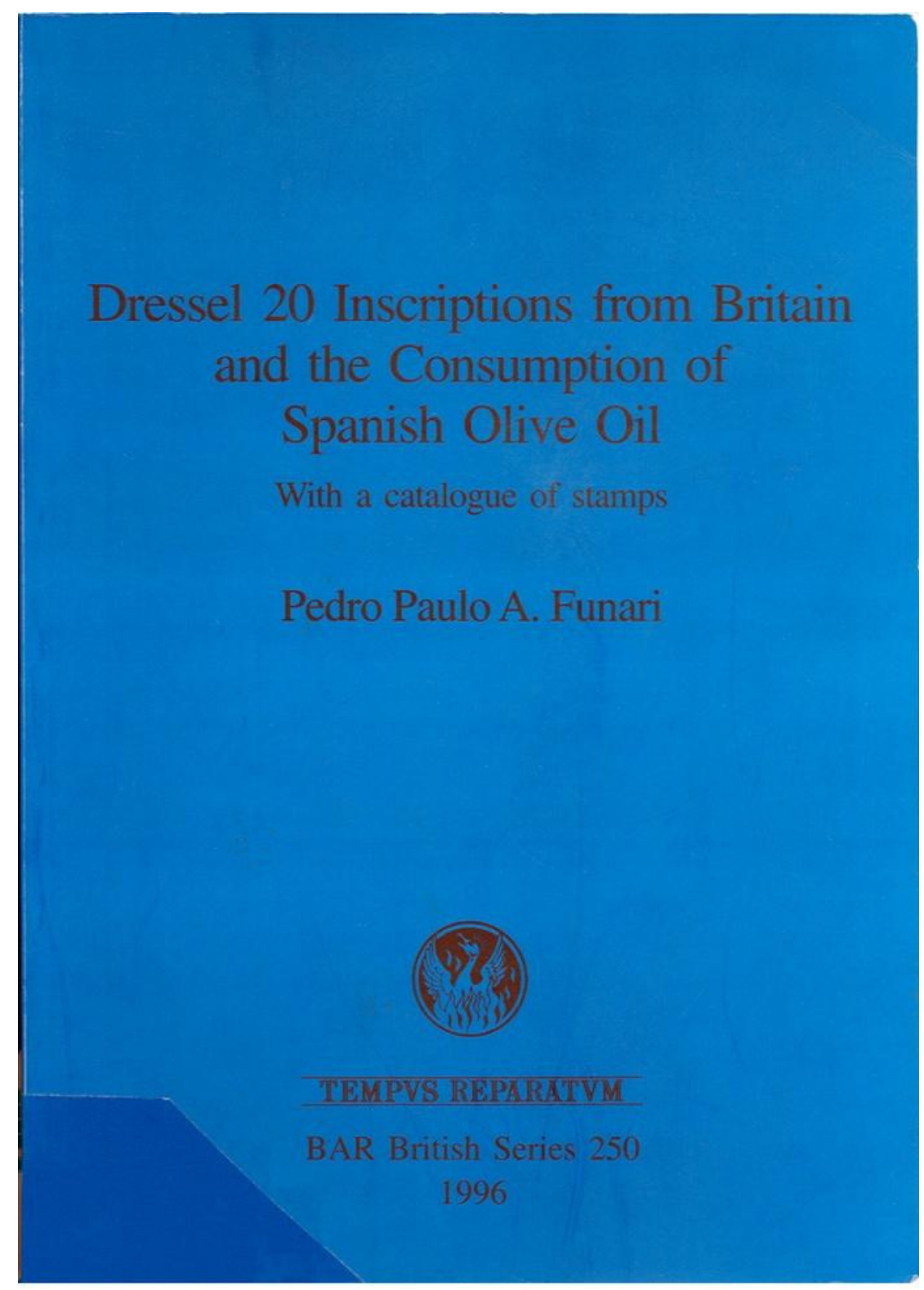

Figura 1. Capa da publicação. Oxford, 1996.

Largely focused on the epigraphy of Dressel 20 amphorae found in Britain and their economic consequences (the oil trade in this region during the Roman rule), this work also presented a chronology (of the $3^{\text {rd }}$ century $\mathrm{AD}$ ) and a matrix as comprehensive as possible of what can be inferred from the Dressel 20 amphoric epigraphy, based on painted and graphite inscriptions and seals (Figures 2 and 3). 


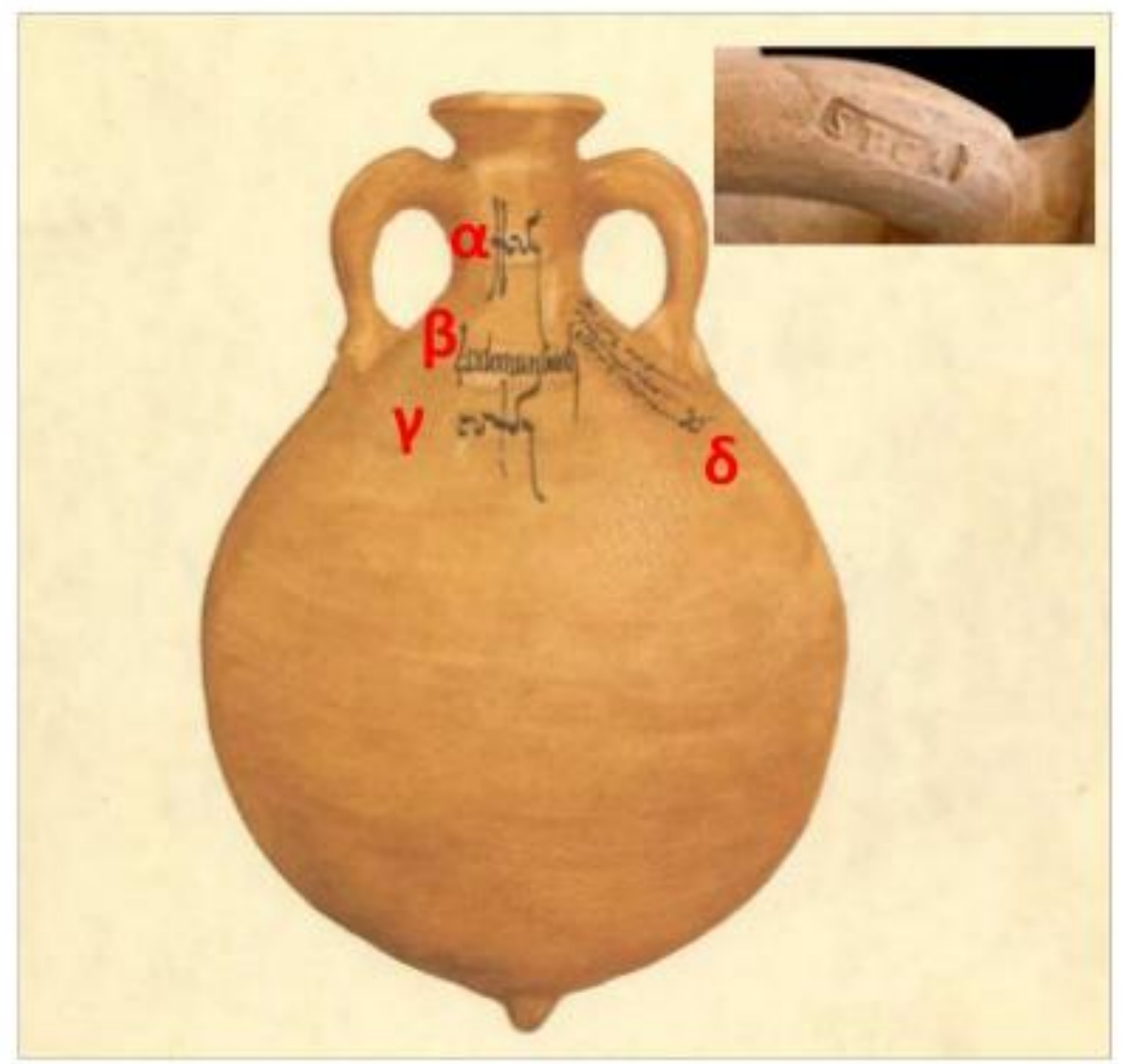

Figura 2. Epigrafia da ânfora Dressel 20; Link: https://goo.gl/images/FYoLSr
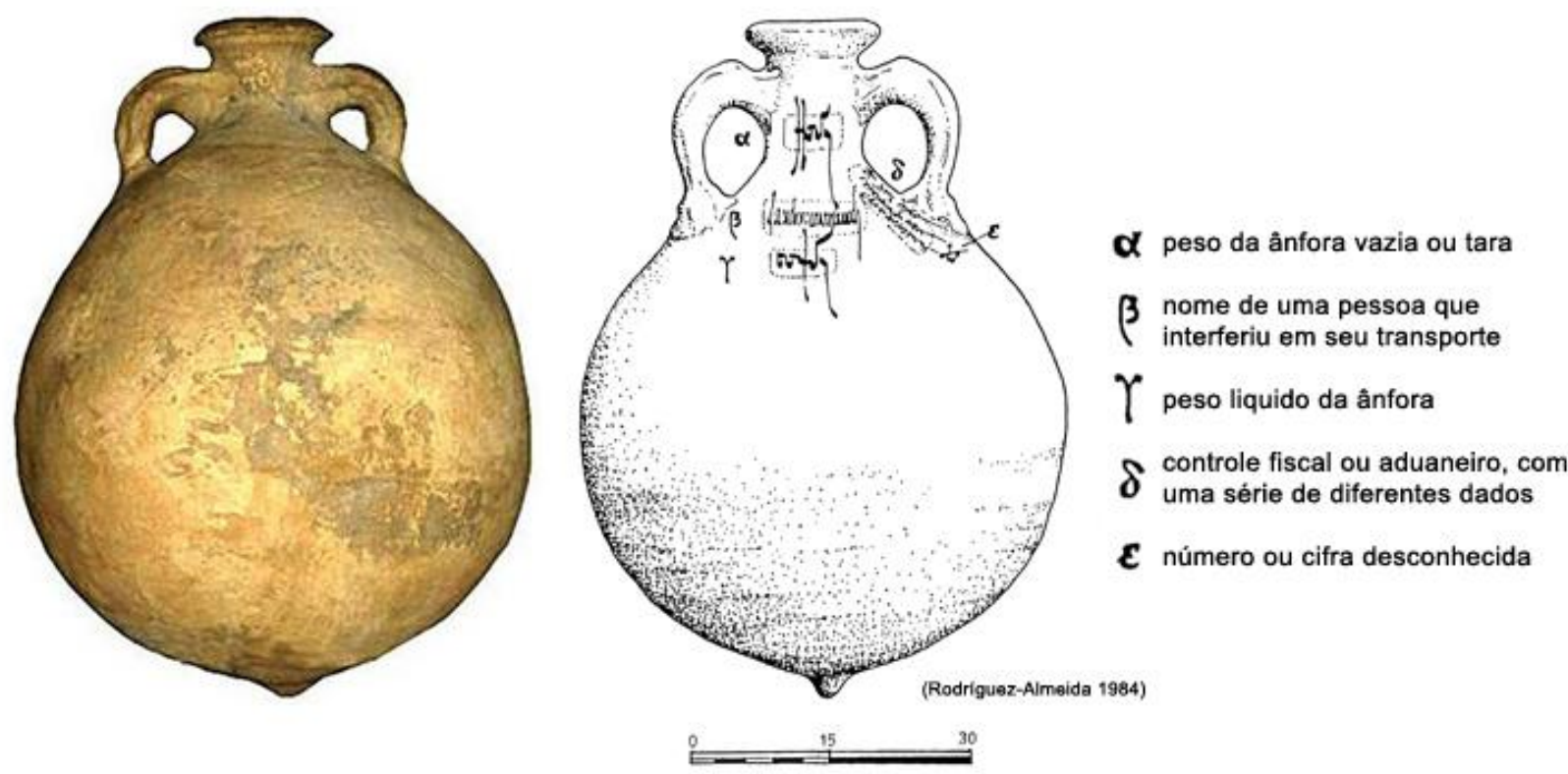

Figura 3. Ânfora Dressel 20 e inscrições. Link: https://goo.gl/images/FyoLSr 
We must also compliment Prof. Funari for his concern and effort to publish amphorae and amphoric inscriptions in museum collections, exemplified by the amphorae he published at the Assis Chateaubriand Art Museum of São Paulo (MASP), at the Verulamium Museum (St. Albans, United Kingdom) and the Archaeology and Ethnology Museum, in São Paulo (MAE-USP). It was not by a lack of interest on his part and of effort, on mine, that nine amphorae from the National Museum (at the Federal University of Rio de Janeiro) were left out of these publications.

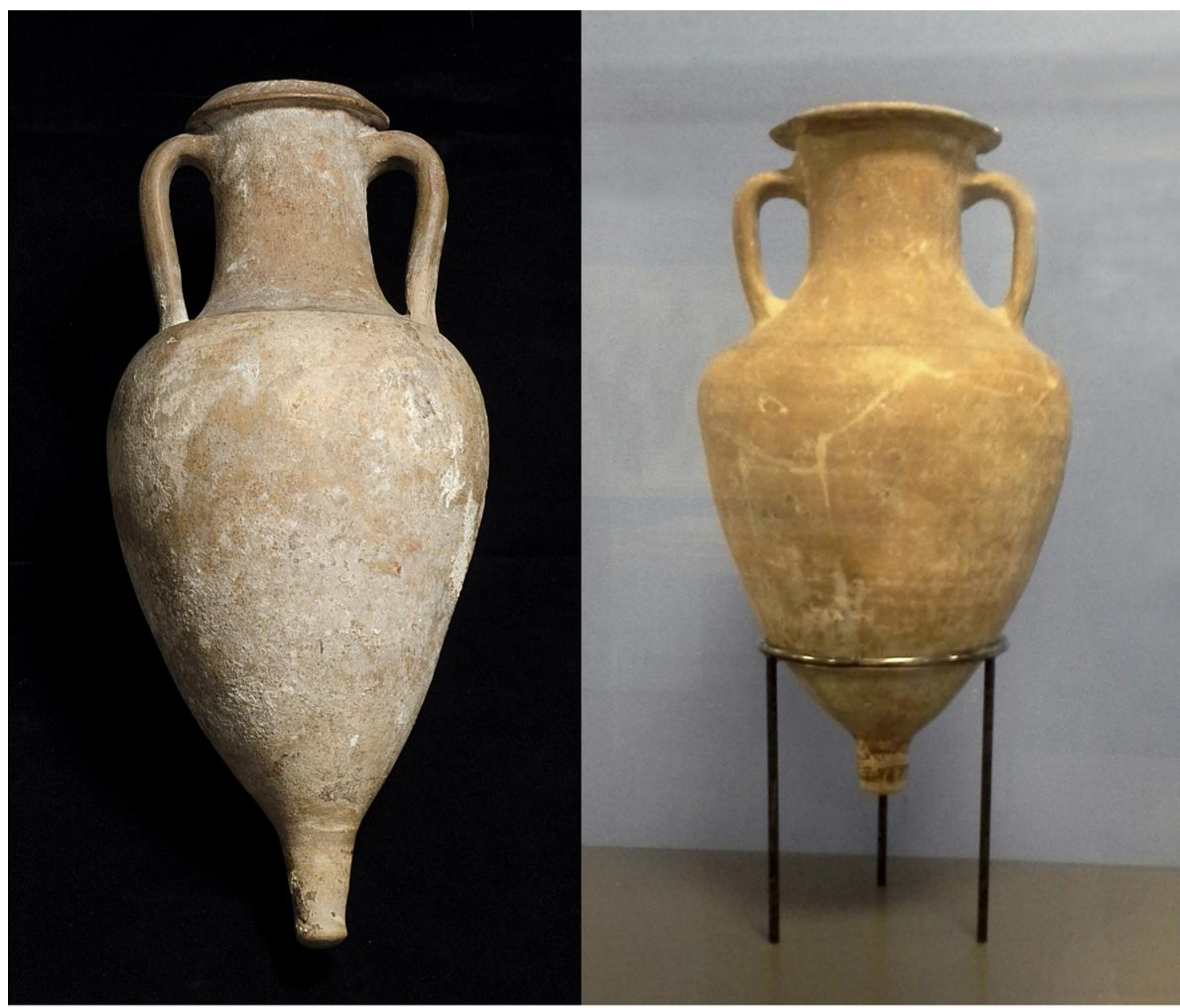

Figura 4. Ânfora greco-itálica. MAE/USP, inv. 64/9.6. Data: 350-250 a.C.. Foto: Ader Gotardo/MAE/USP

Figura 5. Ânfora greco-itálica. MAE/USP, inv. 64/9.5 Data: 350-250 a.C.. Foto: Denise Dal Pino/MAE/USP

- Catálogo de ânforas do MASP ["MASP catalogue of amphorae", in Portuguese]. Boletim. Instituto de História da Arte do MASP. São Paulo: MASP, v. 1, 1997, p. 18-20.

- Dressel 20 stamps from the Verulamium Museum. Revista do Museu de Arqueologia e Etnologia. São Paulo: MAE-USP, v. 9, 1999, p. 143-161. 
Bearing this interest in mind, Prof. Funari went beyond Roman amphorae and Latin epigraphy to pursue the publication of three anepigraphic amphorae (two Greek-Italian, and one Greek), and five amphora handles with Greek stamps (four from Rhodes, and one from Cnidus):

- MAE-USP amphora collection: vessels and inscriptions. Revista do Museu de Arqueologia e Etnologia. São Paulo: MAE-USP, v. 11, 2001, p. 275-282. (Figures 4, 5, 6).

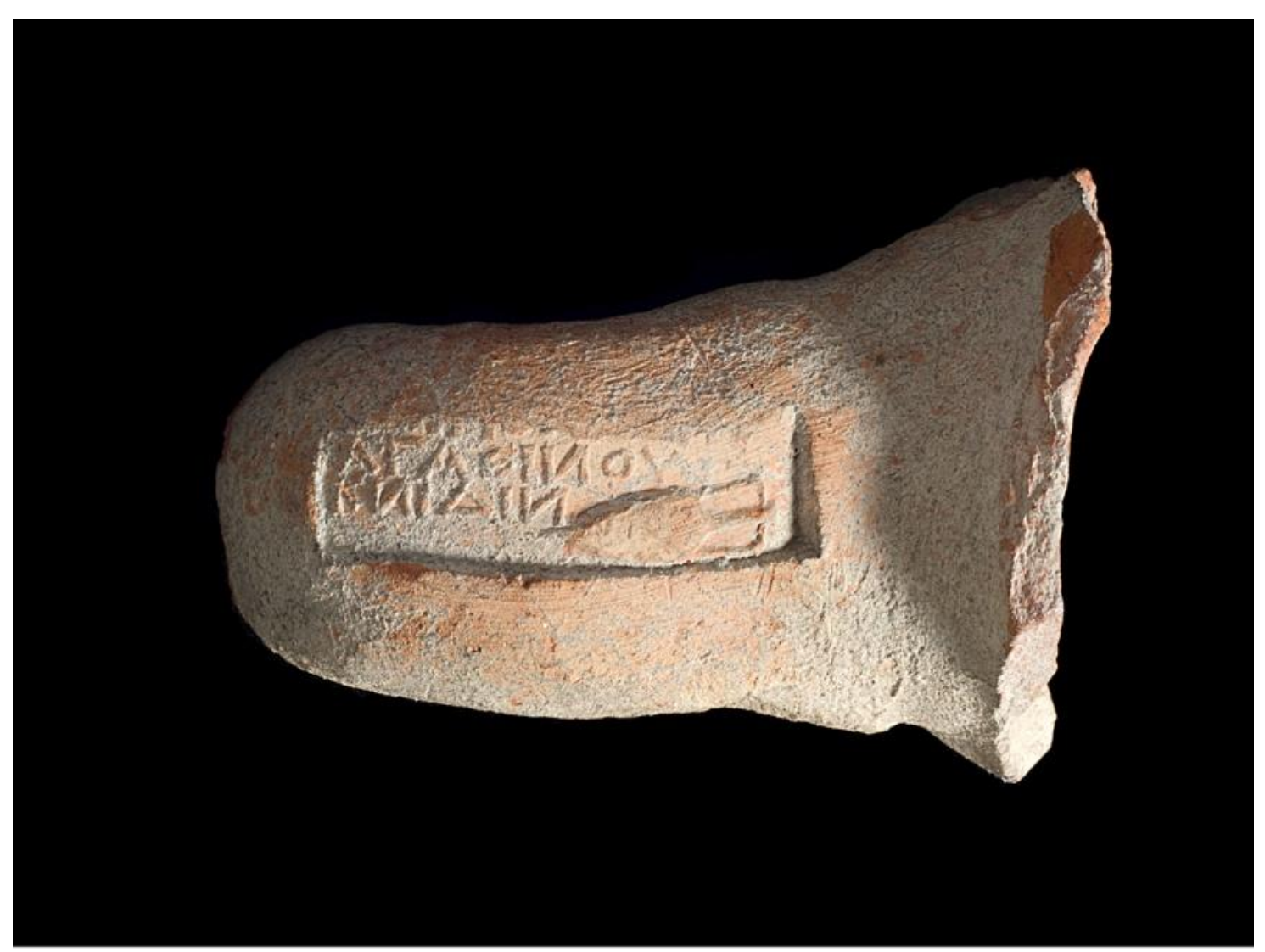

Figura 6. Alça timbrada de ânfora grega (Cnido). MAE-USP, inv. 75/1.43. Data: meados do séc. II a.C.. Foto: Ader Gotardo/MAE/USP

Only in 2014 did Prof. Funari resume his work with this theme that was so dear to him for two decades, by publishing the article:

- Considerações sobre a contribuição da Arqueologia da Bética para o estudo da economia romana. ["Notes on the contributions of Baetican archaeology for the study of Roman economy", in Portuguese] Revista do Museu de Arqueologia e Etnologia. Suplemento. São Paulo: MAE-USP, n. 18, 2014, p. 19-27.

In this article, which affirms the central role of archaeology for the study 
of ancient economy, Prof. Funari studied the case of Baetica and, among other material culture evidences, he highlighted the results that can be obtained via amphoric materials.

To conclude, I recall an excerpt of Socrates' narrative on the invention of writing (274c-275d) in the work Phaedrus by Plato (428 - 347 B.C.): the inventor of writing - the Egyptian god Thot - affirmed that writing is meant to strengthen memory.

Thus, if for many of our colleagues - my own and Prof. Funari's -, such a fruitful period for studies on ceramics has waned from individual memory, now there remain the writings of the initial researches and publications on classical ceramology in Brazil. In this regard, among the many students I have supervised in this academic discipline, Pedro Paulo Abreu Funari was an exemplary pioneer.

\section{Acknowledgments}

I am thankful to Denise Dal Pino (Communication Analyst, MAE-USP) for preparing the figures of this article, and Eleuza Gouveia (former Librarian, MAE-USP) for adjusting its text to the publishing rules of the journal. 